\title{
Benefits of mixing grasses and legumes for herbage yield and nutritive value in Northern Europe and Canada
}

\author{
E. Sturludóttir*†, C. Brophył, G. Bélanger§, A.-M. Gustavssonף, M. Jørgensen**, \\ T. Lunnant† and Á. Helgadóttirt \\ *Faculty of Physical Sciences, University of Iceland, Reykjavík, Iceland, †Agricultural University of Iceland, \\ Keldnaholti, Reykjavik, Iceland, łDepartment of Mathematics and Statistics, National University of Ireland \\ Maynooth, Maynooth, County Kildare, Ireland, §Agriculture and Agri-Food Canada, Quebec City, Quebec, \\ Canada, TDepartment of Agricultural Research for Northern Sweden, Crop Science, Swedish University of \\ Agricultural Sciences, Umeå, Sweden, **Bioforsk - Norwegian Institute for Agricultural and Environmental \\ Research, Tromsø, Norway, ††Bioforsk - Norwegian Institute for Agricultural and Environmental Research, \\ Løken, Heggenes, Norway
}

\begin{abstract}
Increased biodiversity may improve ecosystem services, including herbage yield. A mixture experiment was carried out at five sites in Northern Europe and one in Canada to investigate whether mixtures of grasses and legumes would give higher herbage yield than monocultures. Resistance of the mixtures to weed invasion and nutritive value of the herbage were also investigated. The experimental layout followed a simplex design, where four species differing in specific functional traits, timothy (Phleum pratense L.), smooth meadow grass (Poa pratensis L.), red clover (Trifolium pratense L.) and white clover (Trifolium repens L.), were grown in monocultures and eleven different mixtures with systematically varying proportions of the four species. Positive diversity effects (DE) were observed, leading to greater herbage dry-matter (DM) yield in mixtures than expected from species sown in monocultures. For centroid mixtures, the DE generated on average an additional 32, 25 and $21 \%$ of the DM yield than would be expected from the monocultures in the first, second and third year respectively. On average, the mixtures were 9,15 and $7 \%$ more productive than the most productive monoculture (transgressive overyielding) in the first, second and third year respectively. These benefits persisted over the three harvest years of the experiment and were consistent
\end{abstract}

Correspondence to: Á. Helgadóttir, Agricultural University of Iceland, Keldnaholti, IS-112 Reykjavík, Iceland.

E-mail: aslaug@lbhi.is

Received 3 September 2012; revised 7 December 2012 among most sites. This positive effect was not accompanied by a reduction in herbage digestibility and crude protein concentration that is usually observed with increased DM yield. Mixtures also reduced the invasion of weeds to $<5 \%$ of herbage yield compared to monocultures (10-60\% of herbage yield).

Keywords: diversity effect, grass-legume mixtures, herbage quality, transgressive overyielding

\section{Introduction}

In the light of the present challenges in the production of food, ways must be found to increase the productivity of agricultural land without further increasing the use of external inputs, such as chemical fertilizers, or even preferably by reducing inputs (Foley et al., 2011). There is, thus, increasing demand for sustainable agriculture where outputs (food, fibre, fuel, oil) can be produced over long periods while maintaining ecosystem services without depletion of natural capital (e.g. minerals, biodiversity, soil and clean water). Diverse mixtures of plant species can use resources more efficiently in nutrient-poor environments (Hector, 1998), and they can produce more biomass than communities of one or few species (Hector et al., 1999; Cardinale et al., 2007). In agricultural ecosystems, grass-legume mixtures have the potential to increase productivity, herbage nutritive value and resource efficiency (Peyraud et al., 2009). Recent results of a pan-European experiment, using two grasses and two forage legumes at thirty-one sites for 3 years, have demonstrated strong positive mixing effects (Finn et al., 2012). 
Synthesized $\mathrm{N}$ fertilizer is essential to maintain productive agriculture, but greater use of biological $\mathrm{N}$ fixation in agricultural systems could reduce reliance on synthetic N. It has been shown that grass species can benefit from growing in mixtures with legume species (Temperton et al., 2007), and $\mathrm{N}$ fixation of legume species can be enhanced with competition from nonlegume species (Nyfeler et al., 2011). Low temperatures, however, can constrain the utilization of the $\mathrm{N}$ fixing ability of legumes (Nesheim and Boller, 1991). Low temperatures and harsh winter conditions can also affect the survival of perennial legume species (Wachendorf et al., 2001; Bélanger et al., 2006). Breeding efforts have been carried out to produce cultivars that give high herbage yield and are persistent in mixture with grasses at low temperatures (Helgadóttir et al., 2008).

Different species growing together in a mixture can use resources in different ways, both in space and time, thus avoiding competition and exploiting the environment more efficiently than communities consisting of one or few species (Trenbath, 1974; Hooper, 1998). For example, plants can differ in depth of rooting and, hence, exploit different soil layers (Wilson, 1988), or mixtures can use the sunlight more efficiently than monocultures through improved interception of light (Spehn et al., 2005). Furthermore, components of a mixture may show nutritional complementarity. Legumes, particularly species of the genus Trifolium, can utilize atmospheric $\mathrm{N}$ through their symbiotic $\mathrm{N}$ fixation ability. This can lead to positive interactions between legume and non-legume species through the increase in the soil-N pool provided by the legumes (Mulder et al., 2002). Effects of legumes can persist even if the proportion of legumes in the total biomass is small (Mulder et al., 2002; Nyfeler et al., 2011). Positive interactions have also been observed among non-legume species (e.g. van Ruijven and Berendse, 2003; Hooper and Dukes, 2004).

Losses from weed competition represent a significant waste of resources (water and nutrients) in agricultural systems, and more efficient use of resources in diverse grass-legume mixtures makes them more resistant to the invasion of weeds than communities composed of fewer species (Frankow-Lindberg et al., 2009). Greater evenness of species in a mixture further increases their resistance to weed invasion (Tracy and Sanderson, 2004).

Niche complementary and resistance to weeds and diseases can result in greater yield in mixtures than would be expected from the component species growing separately (Trenbath, 1974). Meta-analysis carried out by Cardinale et al. (2007) showed that mixtures were more productive than the average monoculture (i.e. overyielding) in $79 \%$ of the forty-four experiments they summarized. The most diverse mixture used in the experiments achieved 1.7 times the biomass of the average of the monocultures and 0.88 times the yield of the most productive species grown in monoculture. In $12 \%$ of the experiments, the mixtures were more productive than the most productive monoculture (transgressive overyielding).

While it is desirable in agronomic systems to achieve good yields, it is no less important to obtain herbage of high digestibility, low fibre content and high concentration of protein, to sustain animal production (McDonald et al., 2002). Forage legumes generally have higher nutritive value than grass species, and therefore, growing grasses and legumes in mixtures can improve herbage nutritive value compared with grass monocultures (Zemenchik et al., 2002), due, for example, to slower decline in digestibility with advancing maturity and higher levels of protein (Dewhurst et al., 2009).

The aim of this study was to investigate whether grass-clover mixtures will improve yield and herbage nutritive value compared with growing these species in monocultures under the fairly extreme climatic conditions of Northern Europe and Canada, and if such benefits are present, whether they are consistent across different sites in the northern region and persist over several years.

\section{Materials and methods}

\section{Experimental design and measurements}

A total of fifteen different grassland communities, consisting of various combinations of timothy (Phleum pratense L.), smooth meadow grass (Poa pratensis L.), red clover (Trifolium pratense L.) and white clover (Trifolium repens L.), were established at six sites across Northern Europe and Canada [Iceland (a), Iceland (b), Norway (a), Norway (b), Sweden and Canada] and harvested over a 3-year period (Table 1). The Canadian site had a more continental climate than the four sites in the Nordic countries, as indicated by both higher annual mean temperature and lower temperatures during December, January and February. At each site, four monocultures and eleven four-species mixture communities were sown according to a simplex design (Cornell, 2002) at two levels of overall sown density, with the high level being the recommended seed weight $(100 \%)$ under northern conditions and low being $60 \%$ of high, giving thirty plots at each site and 180 plots in total. At the high sown density, the seeding rates of the monocultures were 20, 24, 12 and $10 \mathrm{~kg} \mathrm{ha}^{-1}$ for timothy, smooth meadow grass, red and white clover, respectively. The fourspecies mixtures varied in the sown proportions of the 
four species, based on the monoculture seeding rate for each species; there was one centroid mixture with equal sowing proportions $(25,25,25$ and $25 \%)$, four mixtures with each species dominant in turn $(70,10$, 10 and $10 \%)$ and six mixtures with two species codominant in turn $(40,40,10$ and $10 \%$ ) (see Kirwan et al., 2007 for more details). The species were categorized into four functional groups: grass/legume $\times$ fast/ slow speed of establishment. Timothy was categorized as a fast-establishing grass, smooth meadow grass as a slow-establishing and persistent grass, red clover as a fast-establishing legume and white clover as a slowestablishing and persistent legume. The experiment reported here was a part of a larger agrodiversity study carried out across Europe (Kirwan et al., 2007; Finn et al., 2012). The sites included here belong to the northern group, identified by the same group of species used.

The experiments were established during 2002 and 2004 (depending on site). A cleaning cut was taken in autumn of the sowing year at five of the six sites. The plots varied in size $\left(6-21 \mathrm{~m}^{2}\right)$, were not weeded and were managed according to local practice for grasslegume mixtures (Table 1). To estimate the dry-matter (DM) yield of each plot, a subplot (not $<3 \mathrm{~m}^{2}$ ) was harvested to a $5-\mathrm{cm}$ height twice over the growing season for 3 years following establishment (three times in Sweden in year 2). The harvest dates varied between sites and years, depending on growing conditions and common practices at each site. Subsamples of the harvested material (grab samples at Iceland (a), Norway (a) and (b) and fixed quadrats of $0.25 \mathrm{~m}^{2}$ at Iceland (b), Sweden and Canada) were separated into the individual sown species and weeds. Dry-matter yield for unseparated samples and all individual components was determined after drying at $55-80^{\circ} \mathrm{C}$ for 60-72 h. The DM yield of sown and unsown species (weeds) was summed to give the harvested DM yield per plot. Dry-matter yields across harvests were summed within each year to give the annual DM yield per plot.

The nutritive value of the harvested herbage, containing both sown species and weeds at each harvest, was measured for each plot at four of the six sites (Iceland (a), Norway (a), Sweden and Canada). For Iceland (a), measurements are missing for co-dominant mixtures in year 1 and for timothy monocultures in year 2. Samples were ground and then scanned using a near-infrared spectrophotometer (NIRS) (FOSS NIRsystems 6500, Silver Spring, MD, USA) to determine acid detergent fibre (ADF), neutral detergent fibre (NDF), in vitro true digestibility (IVTD) and $\mathrm{N}$ concentration. Samples with the highest relative significant spectra were selected as calibration set (fiftyfive samples) and validation set (fifteen samples). Samples of the calibration and validation sets were analysed in duplicate for ADF, NDF, IVTD and N. Analytical dry matter was determined by oven-drying at $105^{\circ} \mathrm{C}$. Nitrogen concentration was determined by a micro-Kjeldahl digestion (Isaac and Johnson, 1976)

Table I Geographic location, climatic conditions, cultivars and management for the six study sites.

\begin{tabular}{|c|c|c|c|c|c|c|}
\hline & \multicolumn{6}{|c|}{ Country } \\
\hline & Iceland (a) & Iceland (b) & Norway (a) & Norway (b) & Sweden & Canada \\
\hline Site* & Reykjavik & Reykjavik & Holt & Loken & Pitea & Lévis \\
\hline Latitude & $64^{\circ} 09^{\prime} \mathrm{N}$ & $64^{\circ} 09^{\prime} \mathrm{N}$ & $69^{\circ} 41^{\prime} \mathrm{N}$ & $61^{\circ} 07^{\prime} \mathrm{N}$ & $65^{\circ} 19^{\prime} \mathrm{N}$ & $46^{\circ} 46^{\prime} \mathrm{N}$ \\
\hline Longitude & $21^{\circ} 45^{\prime} \mathrm{W}$ & $21^{\circ} 45^{\prime} \mathrm{W}$ & $18^{\circ} 56^{\prime} \mathrm{E}$ & $9^{\circ} 04^{\prime} \mathrm{E}$ & $21^{\circ} 24^{\prime} \mathrm{E}$ & $71^{\circ} 12^{\prime} \mathrm{W}$ \\
\hline Elevation (m.a.sl.) & 35 & 35 & 15 & 435 & 5 & 43 \\
\hline Annual rainfall (mm) & 900 & 900 & 1031 & 576 & 539 & 991 \\
\hline Annual temperature $\left({ }^{\circ} \mathrm{C}\right)$ & $4 \cdot 5$ & $4 \cdot 5$ & $3 \cdot 1$ & $1 \cdot 6$ & $2 \cdot 1$ & $4 \cdot 4$ \\
\hline Mean temp. Dec.-Feb. $\left({ }^{\circ} \mathrm{C}\right)$ & $-0 \cdot 8$ & $-0 \cdot 8$ & $-3 \cdot 1$ & $-8 \cdot 8$ & $-10 \cdot 2$ & $-11 \cdot 0$ \\
\hline Year of establishment & 2002 & 2003 & 2002 & 2003 & 2003 & 2004 \\
\hline Timothy & Vega & Vega & Vega & Vega & Vega & Vega \\
\hline Smooth meadow grass & Fylking & Knut & Knut & Knut & Knut & Knut \\
\hline Red clover & Betty & Bjursele & Betty & Betty & Betty & Bjursele \\
\hline White clover & Norstar & Norstar & Norstar & Norstar & Norstar & Norstar \\
\hline Number of harvests & 2 & 2 & 2 & 2 & $2-3$ & 2 \\
\hline $\mathrm{N}$ fertilizer $\left(\mathrm{kg} \mathrm{ha}^{-1}\right.$ year $\left.^{-1}\right)$ & 40 & 80 & 60 & 80 & 60 & 60 \\
\hline P fertilizer $\left(\mathrm{kg} \mathrm{ha}^{-1}\right.$ year $\left.^{-1}\right)$ & 40 & 40 & 25 & 35 & 55 & 24 \\
\hline K fertilizer $\left(\mathrm{kg} \mathrm{ha}^{-1}\right.$ year $\left.^{-1}\right)$ & 60 & 60 & 95 & 100 & 105 & 80 \\
\hline
\end{tabular}

*The experimental sites correspond to the site \# in the COST 852 Agrodiversity Experiment Database as follows: Iceland $(a)=13$, Iceland $(b)=14$, Norway $(a)=23$, Norway $(b)=25$, Sweden $=33$ and Canada $=52$. 
followed by determination on an automated continuous-flow injection analyser (Model QuickChem 8000 FIA; Zellweger Analytics Inc., Lachat Instruments, Milwaukee, WI, USA; method 13-107-06-2-E). The ADF and NDF concentrations were determined using the ANKOM200 Fiber analyzer (Ankom Technology, Fairport, NY, USA). The IVTD was measured using the method of Goering and van Soest (1970) based on a 48-h incubation with buffered rumen fluid followed by an NDF wash of the post-digestion residues using the ANKOM DaisyII incubator. The concentrations of $\mathrm{ADF}, \mathrm{NDF}, \mathrm{N}$, and IVTD were then predicted in all samples using the selected NIRS calibration equations. The NIRS predictions were considered successful with ratios of prediction to deviation (RPD) $>3.0$ (Nie et al., 2009). Crude protein (CP) concentration was calculated by multiplying the $\mathrm{N}$ concentration by $6 \cdot 25$, and in vitro cell wall digestibility (IVCWD) was calculated using the following equation:

IVCWD $=1000-[(1000-$ IVTD $) /(\mathrm{NDF} / 1000)]$

Annual weighted averages of nutritive value for every plot were calculated as:

$$
Q V_{i}=\sum_{j=1}^{h}\left(Q M_{i j} \times y_{j}\right) / \sum_{j=1}^{h} y_{j}
$$

where $\mathrm{QM}_{i j}$ is the nutritive value $i$ in harvest $j$, and $y_{j}$ is the DM yield of harvest $j$, and $\mathrm{QV}_{i}$ is the annual measure for nutritive value $i$.

\section{Statistical analysis}

We modelled the annual DM yield and nutritive value attributes using a diversity-interaction model (Kirwan et al., 2007, 2009):

$$
y=\sum_{1 \leq i \leq 4} \beta_{i} P_{i}+\alpha M+\sum_{1 \leq i<j \leq 4} \delta_{i j} P_{i} P_{j}+\epsilon
$$

where $P_{i}$ is the sown proportion of species $i, M$ is the plot overall sown density and is coded -1 for low density and 1 for high and $\varepsilon$ is the error term. $\beta_{i}$ is the expected yield of species $i$ grown in monoculture, $\alpha$ is the effect of sown density and $\delta_{i j}$ s are the effects of the interaction between species $i$ and $j$, and $\beta_{i}$ is called the identity effect for species $i$. In the absence of interaction between species, the expected response $y$ for a mixture community at average density $(M=0)$ is the sum of the identity effects of species in the community weighted by their sown proportions, $\sum \beta_{i} P_{i}$. If there are interactions between species, the expected response $y$ becomes the sum of weighted identity effects plus the diversity effect (DE) (additional effect caused by species mixing). In model [1], the DE is the sum of the pairwise interaction effects, each weighted by the product of the sown proportion of the two interacting species, $\mathrm{DE}=\sum \delta_{i j} P_{i} P_{j}$. We fitted several variants of model [1] where the form of the DE was manipulated in various ways that included constraining all $\delta_{i j}=0$, constraining all $\delta_{i j}$ equal to a constant $\delta$ and having some constraints among the $\delta_{i j}$ related to species functional group classification. For the model with all $\delta_{i j}=\delta$, we defined a scaled version of the sum of the pairwise products of the sown proportions $E=(2 * 4 /$ $(4-1)) \sum P_{i} P_{j}$, where $E=0$ for a monoculture and $E=1$ for a four-species centroid (Kirwan et al., 2007). In the current design, $E$ takes values $0,0.64,0.88$ or 1. Each variant of the diversity-interaction model can be related to a specific biological hypothesis (Kirwan et al., 2009).

The annual DM yield and nutritive-value attributes were each modelled in a combined analysis with data from all sites and all years. Each model was fitted as a random-coefficient model (Verbeke and Molenberghs, 2000; Littell et al., 2006) with each coefficient crossed with year and assumed random across sites within each year. The covariance matrix for the error term allowed for the repeated measures across years structure in the data. The mixed models were fitted using either maximum likelihood (ML) or restricted maximum likelihood (REML) using the MIXED procedure in SAS/STAT ${ }^{\circledR}$ software (SAS Institute Inc, Cary, NC, USA). We used likelihood ratio tests to compare hierarchical models and AIC to compare non-hierarchical models (Pawitan, 2001; Burnham and Anderson, 2002), and compared models were fitted using REML to choose the most suitable error structure and using ML to choose the covariates to be included (Wolfinger, 1993). We also fitted diversity-interaction models to the annual DM yield from each site separately to estimate site-specific DEs.

We tested for transgressive overyielding of annual DM yield using the permutation test of Kirwan et al. (2007). This test is biased against the mixtures and is therefore a conservative test. We applied the test to annual DM yield averaged across sown densities and sites for each year. We also tested for transgressive underyielding of annual DM yield of weeds using the same permutation test on values averaged across sown densities and sites for each year.

We performed a second analysis on the nutritivevalue attributes to examine how, on average, mixtures compared to each monoculture. For each combination of community and sown density, responses were averaged across sites giving a total of thirty values (fifteen communities by two sown densities) for each year. These values were analysed separately for each response and each year by two-way ANOva using the GLM procedure in the SAS/STAT software (SAS 
Institute Inc). The first factor had five levels to differentiate mixtures and each of the monocultures (mixture and monocultures of timothy, smooth meadow grass, red clover and white clover), and the second factor had two levels for sown density (low and high). Average values for the mixtures were then compared with the average values for each monoculture within each year, using a Bonferroni adjustment for multiple comparisons.

\section{Results}

\section{Dry-matter yield}

The best diversity-interaction model that fitted the annual DM yield is given in Table 2. Sown density was not significant in the model, and the results that follow are for average density $(M=0)$. The predicted diversity effect $\left(\mathrm{DE}=\hat{\delta}_{1} E+\hat{\delta}_{2} E^{2}\right)$ was positive for all values of $E$ in each year (Figure 1) $(P<0.05$ for each test when $E=0.64,0.88$ and 1.0 in years 1,2 and 3$)$. The DEs became stronger with increasing evenness of the mixtures, although there was a saturating effect in each year (Figure 1). The positive DE means that mixtures yielded more herbage than would be expected from a weighted average of the monocultures. Specifically for the centroid mixtures, the DE generated on average an additional 32, 25 and $21 \%$ of the DM yield

Table 2 Models for dry-matter yield, neutral detergent fibre (NDF), in vitro true digestibility (IVTD), in vitro cell-wall digestibility (IVCWD) and crude protein (CP).

\begin{tabular}{ll}
\hline Variable & Model \\
\hline Yield & $y=\sum_{i=1}^{4} \beta_{i} P_{i}+\alpha M+\delta_{1} E+\delta_{2} E^{2}+\epsilon$ \\
$\mathrm{NDF}$ & $y=\sum_{i=1}^{4} \beta_{i} P_{i}+\alpha M+\delta E+\epsilon$ \\
IVTD & $y=\sum_{i=1}^{4} \beta_{i} P_{i}+\alpha M+\delta_{1} G L+\delta_{2} G G+\delta_{3} L L+\epsilon$ \\
IVCWD & $y=\sum_{i=1}^{4} \beta_{i} P_{i}+\alpha M+\delta_{1} G L+\delta_{2} G G+\delta_{3} L L+\epsilon$ \\
CP & $y=\sum_{i=1}^{4} \beta_{i} P_{i}+\alpha M+\sum_{1 \leq i<j \leq 4} \delta_{i j} P_{i} P_{j}+\epsilon$
\end{tabular}

$P=$ sown proportion of species i, $M=$ density (coded as -1 for low and 1 for high), $E=$ evenness (ranging from 0 for monocultures to 1 for the centroid mixture), $G=$ sown proportion of the grass species and $L=$ sown proportion of the legume species). that would be expected from the monocultures for the first, second and third year respectively (Figure 2, primary $y$-axis). When DM yield was modelled for each site separately, the DEs were positive and significant at all sites and all years, except at the Canadian site where the DEs were not significant for the first 2 years but were significantly negative in the third year (Table 3). The highest yield benefit of mixtures was observed at Iceland (b) in year 1 .

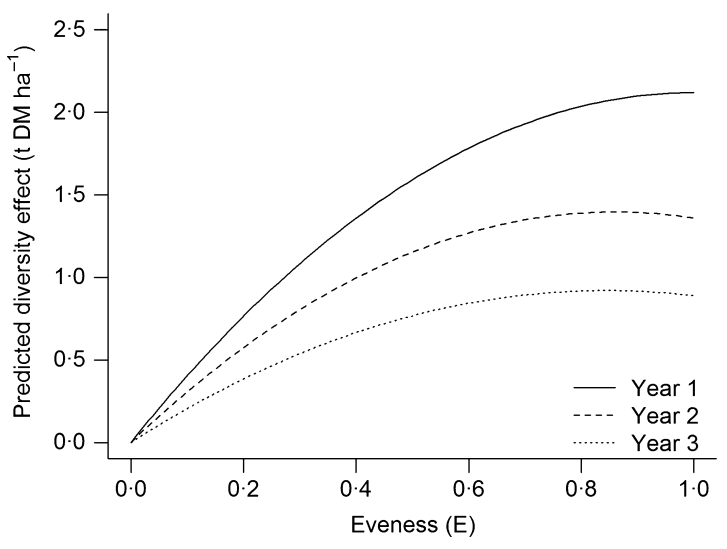

Figure I Predicted diversity effect on dry-matter yield vs. evenness for the 3 years. The evenness values in our experiment were $E=0$ for monocultures, $E=0.64$ for communities dominated by one species, $E=0.88$ for communities co-dominated by two species and $E=1$ for centroid communities where all species were sown equally.

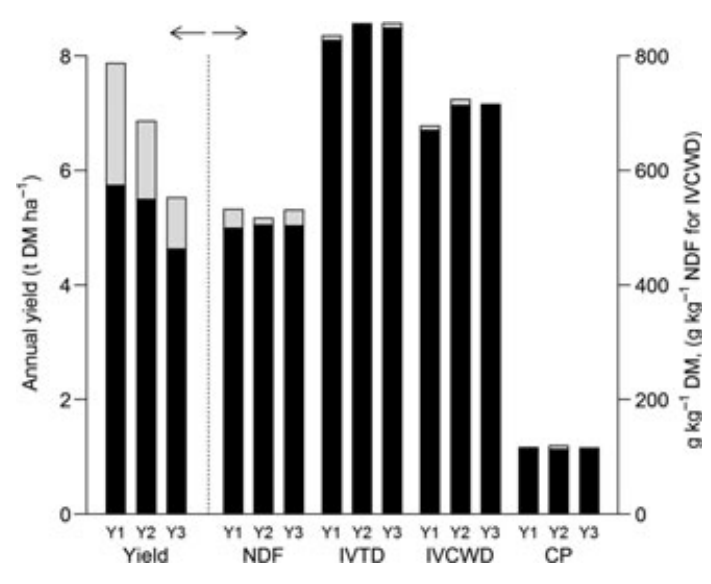

Figure 2 Predicted annual dry-matter yield, six sites combined (axis I) and nutritive-value attributes, four sites combined (axis 2) for the centroid mixture partitioned into predicted yield based on mixture components grown in monoculture $(\mathbf{\square})$ and predicted diversity effect $(\square)$ for each year (YI-Y3) (the models used are shown in Table 2). 
There was evidence of transgressive overyielding $(P<0.01)$ in each of the 3 years when annual herbage DM yield was averaged over sown densities and sites. Almost all of the eleven mixtures were more productive than the most productive monoculture in each year (Figure 3 ). On average, the mixtures were 9,15 and $7 \%$ more productive than the most productive monoculture in the first, second and third years respectively.

The species were sown in mixtures in varied proportions which, when averaged across the eleven mixtures, give $25 \%$ of each species. We observed that the proportions of the sown species in the total herbage DM yield changed considerably over time (Figure 4). Averaged over all mixtures and sites, the proportion of

Table 3 The predicted diversity effect for centroid communities expressed as percentage increase/decrease from the annual dry-matter yield predicted solely from monoculture performance for each site and year separately.

\begin{tabular}{lccc}
\hline \multicolumn{1}{c}{ Site } & Year 1 & Year 2 & Year 3 \\
& $\Delta \%$ & $\Delta \%$ & $\Delta \%$ \\
\hline Iceland (a) & $\mathbf{2 5}$ & $\mathbf{1 4}$ & $\mathbf{1 8}$ \\
Iceland (b) & $\mathbf{8 4}$ & $\mathbf{5 0}$ & $\mathbf{3 5}$ \\
Norway (a) & $\mathbf{5 0}$ & $\mathbf{3 4}$ & $\mathbf{3 4}$ \\
Norway (b) & $\mathbf{2 8}$ & $\mathbf{2 9}$ & $\mathbf{1 8}$ \\
Sweden & $\mathbf{3 2}$ & $\mathbf{3 8}$ & $\mathbf{3 6}$ \\
Canada & 12 & 2 & $-\mathbf{7}$ \\
\hline
\end{tabular}

Bold font indicates values significant at $P<0.05$.

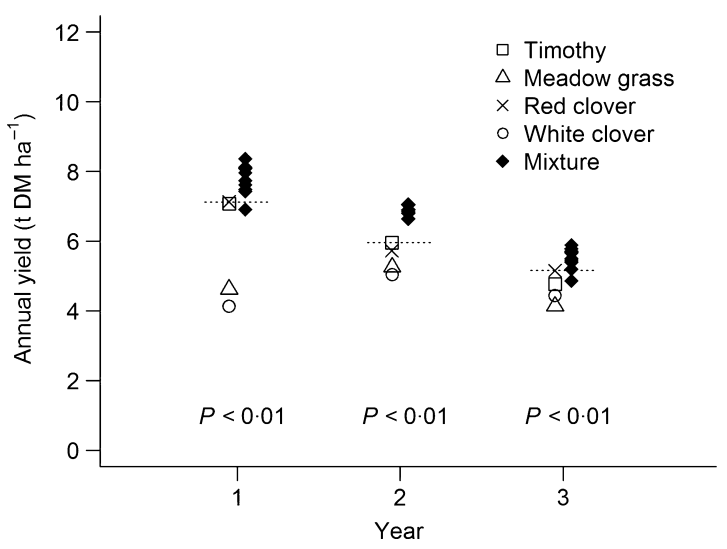

Figure 3 Annual dry-matter yield of the eleven mixtures and four monocultures (timothy, smooth meadow grass, red clover and white clover), averaged over sown densities and sites for each year. The dotted lines highlight the mostproductive monoculture in each year. $P$ values are for the test for transgressive overyielding. smooth meadow grass increased from around 15\% to almost $50 \%$ of the total herbage DM yield, whereas timothy contributed half of the herbage DM yield in the first year but $<30 \%$ in the third year (Figure 4 ). The proportion of red clover was reduced from $20 \%$ in the first year to $10 \%$ in the second year and then remained constant. The proportion of white clover was fairly constant throughout.

The mixtures were more resistant to weeds than the most resistant species grown in monoculture (Figure 5). Weeds made up around 5\% of the total herbage DM yield of mixtures, whereas clover monocultures were highly invaded. When averaged over sites and sown densities, the test for transgressive underyielding of weeds was significant for all the 3 years $(P<0 \cdot 01)$.

\section{Nutritive value}

The best diversity-interaction model for each nutritive value attribute can been seen in Table 2 . There were significant interaction effects for each of the nutritive value attributes, but these interactions were either positive or negative and therefore tended to cancel each other out when aggregated. This means that the DE was not significant in most cases for the centroid mixtures, except for a significant positive DE for NDF concentration in the first year $(P<0.05)$ and for IVCWD in the second year $(P<0.01)$ (Figure 2 , secondary $y$-axis). Note that Figure 2 compares the performance of a centroid mixture (black plus grey section of bar) to the weighted average of the four monoculture performances (black section of bar).

The second analysis of the nutritive value attributes by ANOva revealed that there was a significant effect of

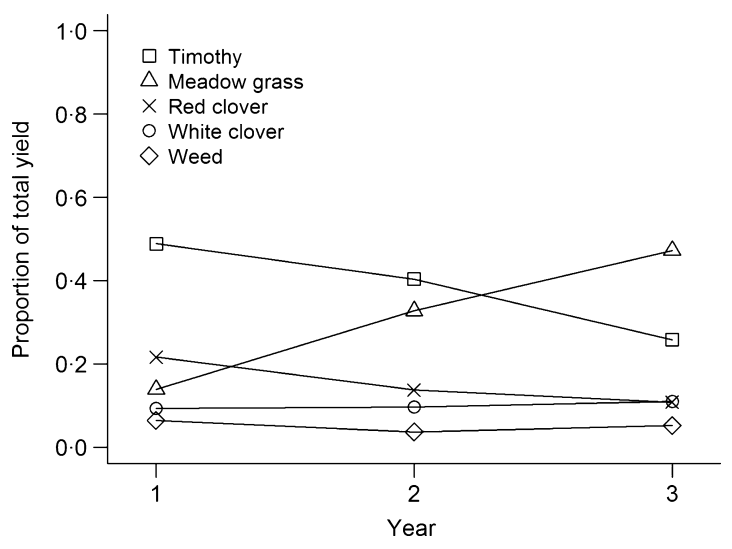

Figure 4 Changes in species proportion of timothy, smooth meadow grass, red clover, white clover and weed, averaged over all mixtures and sites. 


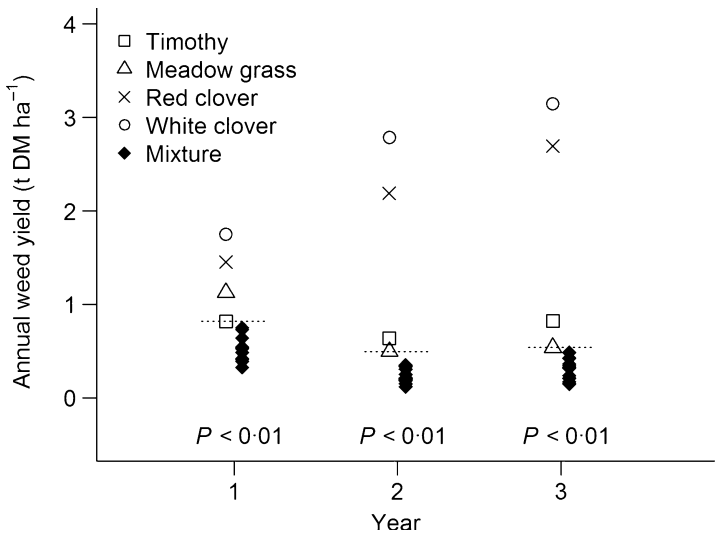

Figure 5 Annual dry-matter yield of weeds in the eleven mixtures and four monocultures (timothy, smooth meadow grass, red clover and white clover), averaged over sown densities and sites for each year. The dotted lines highlight the most-resistant monoculture to weeds in each year. $P$ values are for the test for transgressive underyielding.

community for all attributes. Density effects were not significant for any of the attributes and were therefore dropped from the models. The results from Bonferroni's multiple comparisons showed that the average of all mixtures differed from the four monocultures for some of the nutritive-value attributes. The timothy monoculture had a higher NDF concentration than the mixtures in the first $(+15 \%)$ and second $(+13 \%)$ year $(P<0.001$ for both tests) while the white and red clover monocultures had a lower NDF concentration $(-10$ to $-20 \%)$ than the mixtures in all 3 years $(P<0.001$ for each test) (Figure 6). The timothy monoculture had a lower IVTD $(-2 \%)$ than the mixtures in both the first and second year $(P<0.05)$ while the white clover monoculture had a higher IVTD than the mixtures in the first $(+3 \% ; P<0.01)$ and third year $(+0.6 \% ; P<0.001)$, and the red clover monoculture had a higher IVTD in the first year $(+2 \% ; P<0.001)$. Timothy had a higher IVCWD than the mixtures in the first $(+4 \% ; P<0.05)$ and third year $(+3 \% ; P<0.01)$. The white and red clover monocultures had a lower IVCWD than the mixtures in the second year ( -2 to $-4 \% ; P<0.01$ for both tests), and the red clover monoculture had a lower IVCWD in the third year $(-4 \% ; P<0.01)$. Mixtures and smooth meadow grass monocultures did not differ significantly for NDF concentration, IVTD and IVCWD. Timothy and smooth meadow grass monocultures had lower $\mathrm{CP}$ concentrations than the mixtures in the first $(-26$ and $-24 \%)$, second $(-16$ and $-21 \%)$ and third $(-16$ and $-15 \%)$ year $(P<0.01$ for each test $)$. Red clover had a higher CP concentration than the mixtures in the first year $(+25 \% ; P<0.001)$ but the difference was not significant in the second and third year. The white clover monoculture had a significantly higher CP concentration $(+18$ to $22 \%)$ than the mixtures in each of the 3 years $(P<0.01)$ (Figure 6).

\section{Discussion}

\section{Yield advantage of mixtures}

The herbage yield from the mixtures was more than that expected from the weighted monoculture performances. The model for DM yield, when all sites were combined, showed positive DEs where interactions between each pair of species were assumed to be equal. The interaction between the fast-growing grass and slow-growing legume was equal in strength to the interaction between the fast- and slow-growing grasses. In this experiment, the four agronomic species to be grown together in the mixture were selected $a$ priori to maximize the positive interspecific interactions. Red and white clover use the atmosphere as a source of $\mathrm{N}$ and to increase the $\mathrm{N}$ pool in the soil and are therefore not competing as strongly with the grass species for soil $\mathrm{N}$ (Paynel et al., 2008). The species are also complementary in time, as timothy and red clover establish faster than smooth meadow grass and white clover. Red clover is short lived, whereas white clover can persist for many years. Thus, it has been shown that beneficial effects of mixing grasses and legumes may result from differences in their seasonal growth pattern (Lüscher et al., 2005) or across years (Nyfeler et al., 2009). Timothy and red clover are tall and erect, whereas smooth meadow grass and white clover are short and prostrate. This can lead to more efficient use of resources such as light when grown together than when grown separately. All these different functional traits could have contributed to positive interactions between these species resulting in total DEs for the mixtures. The positive DEs observed here are consistent with other studies that have shown that positive interactions exist in grasslands, both in swards containing grasses and legumes (Spehn et al., 2005; Kirwan et al., 2007; Temperton et al., 2007) and also in grass swards without legumes (Trenbath, 1974; van Ruijven and Berendse, 2003).

If the interspecific interactions are sufficiently strong, the net effect will be transgressive overyielding (Trenbath, 1974). In our study, the mixtures were, in most cases, more productive than the most productive monoculture in each year. In the meta-analysis carried out by Cardinale et al. (2007) only 12\% of the fortyfour experiments indicated transgressive overyielding when mixtures were compared to the most productive species in the experiment but not necessarily in the mixture. The strength of the DEs needed to reach 

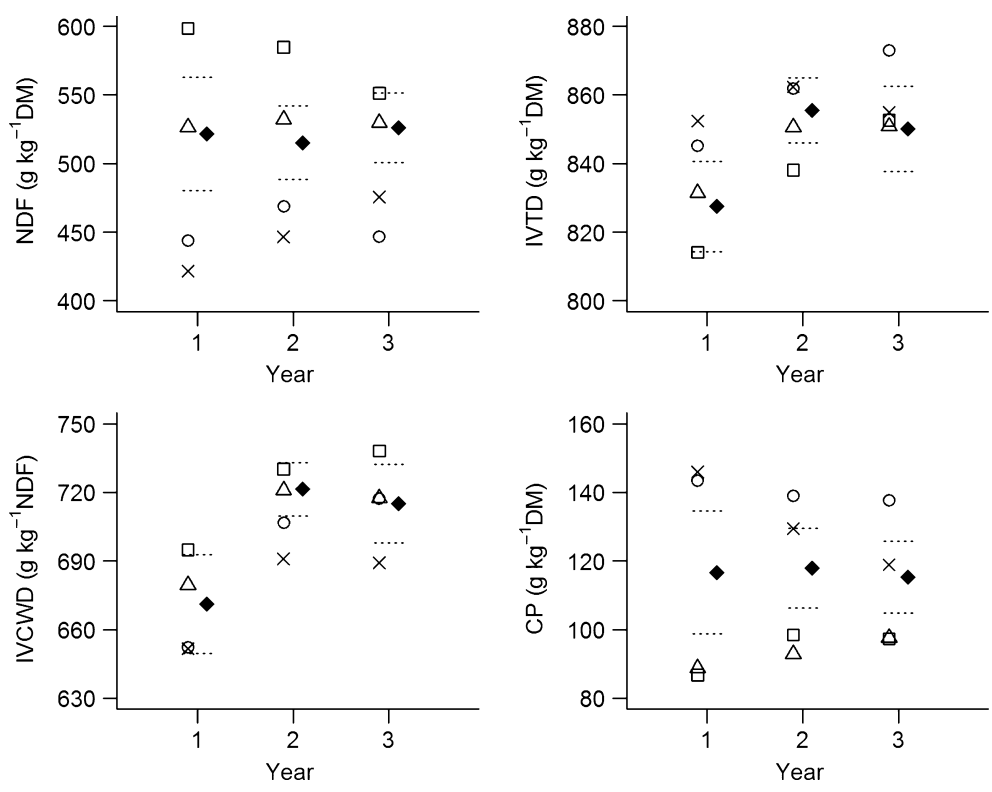

Figure 6 Average nutritive value of the mixtures $(\downarrow)$ and the four monocultures [timothy $(\square)$, smooth meadow grass $(\Delta)$, red clover $(x)$ and white clover $(0)$ ], averaged over four sites. The dotted lines show $95 \%$ Bonferroni decision limits, monocultures outside the limits are significantly different from the mixtures.

transgressive overyielding increases with the number of species in the mixture and also with increasing variation of yield between those species grown in monoculture (Schmid et al., 2008). In this study, on the other hand, there were four high-yielding agricultural species selected a priori confirming the importance of selecting species with differences in specific functional traits. Transgressive overyielding has also been observed in Switzerland (Nyfeler et al., 2009) and in mid-European and dry Mediterranean environments when two legume species and two grass species were grown together in a mixture (Kirwan et al., 2007; Finn et al., 2012).

The DEs became stronger as evenness increased, but they became saturated as evenness approached one in each year (Figure 1). This agrees with several previous studies (e.g. Hector et al., 1999; Tilman et al., 2001; Hooper et al., 2005), although those studies typically used species richness as the measure of diversity. Manipulation of mixture evenness has been found to play an important role in ecosystem functions (e.g. Wilsey and Potvin, 2000; Kirwan et al., 2007), but it has also been acknowledged that the effects of evenness require further study (Wilsey et al., 2005; Hillebrand et al., 2008). The evenness values for sown proportions of the mixtures in this study were 0.64 , $0 \cdot 88$ and $1 \cdot 0$, and as such, they had similar DEs to each other (when compared within each year) because of the saturation effects (Figure 1). In future studies, it would be useful to manipulate a wider range of evenness values. Nonetheless, it is clear from our results that increasing evenness increased DEs.

It is generally considered that the effects of species complementarity become stronger with time (Cardinale et al., 2007). In our study, although the DEs persisted over 3 years, they did not generally increase with time, and strong positive DEs were even found in the first year. The duration of our experiment was relatively short, so it is possible that over a longer time period the observed effects would increase further as was found by Reich et al. (2012). In agronomic systems, it is common to study the effects over a 3-year period, but it is highly relevant to consider a longer time frame as permanent grasslands are common in northern areas.

In this experiment, the application of $\mathrm{N}$ fertilizer ranged from 40 to $80 \mathrm{~kg} \mathrm{~N}^{-1}$, which is lower than normal applications to grass monocultures for herbage production. Grass species will not produce maximum herbage yield under such conditions, especially timothy, which is known to have high $\mathrm{N}$-fertilizer requirements. The DEs might be less or none under higher levels of fertilizer application. Low levels of fertilizer were used in this study to enhance the persistence of the clover species and maximize the positive effects of the grass-legume mixtures. In Switzerland, where two legume and two grass species were grown under three levels of $\mathrm{N}$ fertilizer, the DEs decreased with increasing 
$\mathrm{N}$ fertilization but were still significant at $450 \mathrm{~kg} \mathrm{~N} \mathrm{ha}^{-1}$ (Nyfeler et al., 2009).

The DEs varied between sites, being highest at the Icelandic (b) site and absent at the Canadian site. The experiment at the Icelandic (b) site was carried out on soils classified as Vitric Andosols (classification: WRB), which are low in organic matter (Arnalds, 2008), and this may possibly have resulted in the observed high DEs. The two clover species survived poorly at the Canadian site, resulting in low clover proportions in the second and third years, possibly explaining no and negative DEs observed at this site. No evidence of pests or diseases was observed at this site. Although the legume varieties used in the study are known to be winter tolerant in the Nordic countries, they have not been tested nor are they recommended in Canada. They were possibly not well adapted to the conditions where the Canadian experiment was carried out. The benefits of legumes were evident in the northern environments despite the generally poor persistence of forage legumes in these regions and poor $\mathrm{N}$ fixation rates at low temperatures (Nesheim and Boller, 1991).

\section{Resistance to weed invasion}

Mixtures resisted the invasion of weeds, which made up only about $5 \%$ of their total herbage yield when averaged over sites. In comparison, weeds were 10$20 \%$ and $35-60 \%$ of the total herbage yield of the grass and clover monocultures respectively. The positive DEs demonstrate that mixtures use available resources more efficiently than monocultures, thus making fewer resources available for weeds. It has been postulated that selection effects play an important role in resistance to weed invasion as diverse mixtures are more likely to contain a species that strongly resists the invasion of weeds (Hector et al., 2001). In this study, the mixtures were more resistant to weed invasion than the most resistant species grown in monoculture. This indicates that the selection effects are not solely responsible for the improved resistance in the mixtures. Other experiments have shown reduced invasion with species diversity (Tilman, 1997; Tracy and Sanderson, 2004), but it depends on species (Frankow-Lindberg et al., 2009).

\section{Nutritive value of mixtures}

There were no or only weak DEs on the herbage nutritive-value attributes. This is consistent with observations reported by Deak et al. (2007) that species composition was more important than diversity when determining nutritive value. Herbage nutritive value of forage grasses and legumes is negatively related to DM accumulation (Bélanger et al., 2001).
Hence, increases in herbage DM yield are expected to result in a decrease in nutritive value. The efforts at dissociating herbage yield and nutritive value by genetic selection and management practices have not always been successful. In our study, we could have expected lower nutritive value of the mixtures because of their greater DM yield. This was not the case, and the nutritive value of mixtures was in general similar to that of the monocultures. We can conclude that mixtures improve the relationship between DM yield and nutritive value, making it possible to increase DM yield with no negative effect on the nutritive value.

Even though no significant DEs were observed when comparing mixtures and the average of all monocultures, mixtures of grasses and legumes had much higher CP concentration than grass monocultures, exceeding them by more than $30 \%$ in the first year. Similarly, Sanderson (2010) reported that CP concentration increased with increasing proportion of legumes. In this study, the $\mathrm{N}$ application rate was low, and CP concentration of grasses is known to increase with higher $\mathrm{N}$ rates (Buxton, 1996; Zemenchik et al., 2002). Mixtures with legumes have, however, been found to have higher $\mathrm{CP}$ concentration compared to grasses fertilized with $224 \mathrm{~kg} \mathrm{~N}^{-1}$ (Zemenchik et al., 2002). In this study, we considered the more traditional attributes of nutritive value (digestibility, fibre concentration and CP concentration). Other attributes related to protein degradation in relation to easily fermentable carbohydrates might be affected by mixtures (Gierus et al., 2012). Forage legumes are important sources of protein for ruminants; their protein, however, is often poorly utilized by the animal (Dewhurst et al., 2009). The high CP concentration in forage legumes and its fast degradation rate compared to the amount of fermentable organic matter available in the rumen may lead to inefficient utilization of the $\mathrm{N}$ by ruminants, resulting in high $\mathrm{N}$ losses to the environment. The benefits of mixtures over monocultures for the energy-protein balance remain to be determined.

Along with increasing CP concentration, mixtures of legumes with grasses tended to increase IVTD, primarily when timothy is considered. Overall, our results are consistent with other mixture experiments where it was observed that including legumes with grasses improved herbage nutritive value compared to grass monocultures (Sleugh et al., 2000; Zemenchik et al., 2002; Kunelius et al., 2006). The clover monocultures had a greater CP concentration than the mixtures along with a slightly greater IVTD but they may not be suitable as herbage without being mixed with grasses, because of risk of bloat or infertility.

Grass monocultures tended to have higher NDF concentrations than clover monocultures but also a 
greater digestibility of the cell wall or NDF. As a result, grass monocultures tended to have a slightly lower IVTD or digestibility of the DM than the clover monocultures. Grass monocultures also had much lower CP concentrations than clover monocultures. These differences between grass and legume species are well known (Pelletier et al., 2010), and they are confirmed by our results.

The herbage nutritive values were measured for the total herbage DM yield, including weeds and thus may not always represent the nutritive value of the sown species. Plots that were highly invaded by weeds showed poorer nutritive value because weeds are usually of poor nutritive value. This was evident with the clover monocultures where the herbage had good nutritive value in the first year, but in the third year, when the proportion of weeds was higher, the nutritive value was poorer, especially in red clover swards. The mixtures were more resistant to weed invasion than the grass and clover monocultures, thereby sustaining the herbage nutritive value.

\section{Conclusions}

Growing timothy, smooth meadow grass, red clover and white clover in a mixture under the fairly extreme climatic conditions of northern Europe and Canada resulted in positive DEs, as the mixtures produced more herbage yield than was expected from monoculture performance. Averaged across sites, the DEs were strong enough to result in transgressive overyielding, that is, the mixtures yielded more than the most productive monoculture. Mixtures also reduced the invasion of weeds. The positive effect of mixtures on herbage DM yield was not accompanied by a reduction in herbage digestibility and CP concentration that usually is observed with increased DM yield. Mixing legumes with grasses increased the CP concentration of the herbage mixture relative to that of grass monocultures. These benefits of mixtures were observed even though they were grown under low temperature, at which the N-fixing ability of the clovers is likely to have been reduced. The benefits also persisted over the 3 years that the experiment was harvested.

\section{Acknowledgments}

Co-ordination of this project was supported by the EU Commission through COST Action 852 'Quality legume-based forage systems for contrasting environments'. The experimental work was supported by the Icelandic Research Fund in Iceland, the CL Behms Foundation in Sweden, and INTERREG KolArctic, The Norwegian Barents Secretariat County governors and
Agriculture of Nordland, Troms and Finnmark in Norway. ES received a study grant from the Agricultural Productivity Fund in Iceland and spent two terms working under the supervision of $\mathrm{CB}$ at the National University of Ireland, Maynooth. CB was supported by an award from Science Foundation Ireland (09/RFP/ EOB2546). The authors acknowledge the technical assistance of Danielle Mongrain with quality analyses and numerous others for assistance with field work.

\section{References}

A R N A L D O. (2008) Soils of Iceland. Icelandic Journal of Earth Sciences (Jökull), 58, 409-421.

Bélanger G., Michaud R., Jefferson P.G., Tremblay G.F. and B R ÉGARD A. (2001) Improving the nutritive value of timothy through management and breeding. Canadian Journal of Plant Science, 81, 577-585.

Bélanger G., Castonguay Y., Bertrand A., Dhont C., Rochette P., Couture L., Drapeau R., Mongrain D., Chalifour F.-P. and Michaud R. (2006) Winter damage to perennial forage crops in eastern Canada: causes, mitigation, and prediction. Canadian Journal of Plant Science, 86, 33-47.

BurnhAM K.P. and ANDERSon D.R. (2002) Model selection and multimodel inference: a practical information-theoretic approach. New York: Springer-Verlag.

Buxton D.R. (1996) Quality-related characteristics of forages as influenced by plant environment and agronomic factors. Animal Feed Science and Technology, 59, 37-49.

Cardinale B.J., Wright J.P., Cadotte M.W., Carroll I.T., Hector A., Srivastava D.S., Loreau M. and Weis J.J. (2007) Impacts of plant diversity on biomass production increase through time because of species complementarity. Proceedings of the National Academy of Sciences of the United States of America, 104, 18123-18128.

CORNELL J.A. (2002) Experiments with mixtures: designs, models, and the analysis of mixture data. Chichester, UK: Wiley.

Deak A., Hall M.H., S anderson M.A. and Archibald D.D. (2007) Production and nutritive value of grazed simple and complex forage mixtures. Agronomy Journal, 99, 814-821.

Dewhurst R.J., Delaby L., Moloney A., Boland T. and LEWIS E. (2009) Nutritive value of forage legumes used for grazing and silage. Irish Journal of Agricultural and Food Research, 48, 167-187.

Finn J.A., Kirwan L., Connolly J., Sebasti À M.T., Helgadottir A. and L Üscher A. (2012) Four-species grass-clover mixtures demonstrate transgressive overyielding and weed suppression in a 3-year continental-scale experiment. Grassland Science in Europe, 17, 186-188.

Foley J.A., Ramankutty N., Brauman K.A., Cassidy E.S., Gerber J.S., Johnston M., Mueller N.D., O'Connell C., Ray D.K., West P.C., Balzer C., Bennett E.M., Carpenter S.R., Hill J., Monfreda 
C., Polasky S., Rockstrom J., Sheehan J., Siebert S., Tilman D. and Zaks D.P.M. (2011) Solutions for a cultivated planet. Nature, 478, 337-342.

Frankow - Lindierg B.E., Brophy C., Collins R.P. and Connolly J. (2009) Biodiversity effects on yield and unsown species invasion in a temperate forage ecosystem. Annals of Botany, 103, 913-921.

Gierus M., Kleen J., Loges R. and Taube F. (2012) Forage legume species determine the nutritional quality of binary mixtures with perennial ryegrass in the first production year. Animal Feed Science and Technology, 172, 150-161.

Goering H.K. and van Soest P.J. (1970) Forage fiber analyses (apparatus, reagents, procedures, and some applications.) Agricultural Handbook No. 379. Washington, DC: ARS-USDA.

Hector A. (1998) The effect of diversity on productivity: detecting the role of species complementarity. Oikos, $\mathbf{8 2}$, 597-599.

Hector A., Schmid B., Beierkuhnlein C., Caldeira M.C., Diemer M., Dimitrakopoulos P.G., Finn J.A., Freitas H., Giller P.S., Good J., Harris R., Hogberg P., Huss-Danell K., Joshi J., Jumpronen A., Korner C., Leadeey P.W., Loreau M., Minns A., Mulder C.P.H., O'Donovan G., Otway S.J., Pereira J.S., Prinz A., Read D.J., SchererLorenzen M., Schulze E.D., Siamantziouras A.S.D., Spehn E.M., Terry A.C., Troumbis A.Y., Woodward F.I., Y Achi S. and LAwton J.H. (1999) Plant diversity and productivity experiments in European grasslands. Science, 286, 1123-1 127.

Hector A., Dobson K., Minns A., Bazeley-White E. and Hartley Lawton J. (2001) Community diversity and invasion resistance: an experimental test in a grassland ecosystem and a review of comparable studies. Ecological Research, 16, 819-831.

Helgad óttir Á., Marum P., Dalmannsd óttir S., Daugstad K., KRistúnsd óttir T.A. and Lunnan T. (2008) Combining winter hardiness and forage yield in white clover (Trifolium repens L.) cultivated in northern environments. Annals of Botany, 102, 825-834.

Hillebrand H., Bennett D.M. and Cadotte M.W. (2008) Consequences of dominance: a review of evenness effects on local and regional ecosystem processes. Ecology, 89, 1510-1520.

Hooper D.U. (1998) The role of complementarity and competition in ecosystem responses to variation in plant diversity. Ecology, 79, 704-719.

Hooper D.U. and Dukes J.S. (2004) Overyielding among plant functional groups in a long-term experiment. Ecology Letters, 7, 95-105.

Hooper D.U., Chapin F.S., Ewel J.J., Hector A., Inchausti P., Lavorel S., Lawton J.H., Lodge D.M., Loreau M., Naeem S., Schmid B., Setala H., Symstad A.J., Vandermeer J. and Warden D.A. (2005) Effects of biodiversity on ecosystem functioning: a consensus of current knowledge. Ecological Monographs, 75, 3-35.

Is A A C R.A. and Johns on W.C. (1976) Determination of total nitrogen in plant tissue, using a block digestor.
Journal of the Association of Official Analytical Chemists, 59, 98-100.

Kirwan L., L ÜScher A., Sebastì̀ M.T., Finn J.A., Collins R.P., Porqueddu C., Helgadottir A., B aAdShaug O.H., Brophy C., Coran C., Dalmannsd óttir S., Delgado I., Elgersma A., Fothergill M., Frankow-Lindberg B.E., Golinski P., Grieu P., Gustavsson A.M., H öglind M., Huguenin-Elie O., Iliadis C., Jørgensen M., Kadziuliene Z., Karyotis T., Lunnan T., Malengier M., Maltoni S., Meyer V., Nyfeler D., Nykanen-Kurki P., Parente J., Smit H.J., Thumm U. and Connolly J. (2007) Evenness drives consistent diversity effects in intensive grassland systems across 28 European sites. Journal of Ecology, 95, 530-539.

Kirwan L., Connolly J., Finn J.A., Brophy C., L ÜSCher A., Nyfeler D. and Sebasti À M.T. (2009) Diversity-interaction modeling: estimating contributions of species identities and interactions to ecosystem function. Ecology, 90, 2032-2038.

Kunelius H.T., Durr G.H., McRae K.B. and Fillmore S.A.E. (2006) Performance of timothy-based grass/ legume mixtures in cold winter region. Journal of Agronomy and Crop Science, 192, 159-167.

Littell R.C., Milimen G.A., Stroup W.R., Wolfinger R.D. and SchabenBerger O. (2006) SAS for mixed models. Cary, NC, USA: SAS Press.

Lüscher A., Fuhrer J. and Newton P.C.D. (2005) Global atmospheric change and its effect on managed grassland systems. In: McGilloway D.A. (ed.) Grassland: a global resource, pp. 251-264. Wageningen:

Wageningen Academic Press.

McDonald P., Edwards R.A., Greenhalgh J.F.D. and Morgan C.A. (2002) Animal nutrition. Harlow: Prentice Hall.

Mulder C.P.H., Jumpronen A., Hogberg P. and Huss D ANELL K. (2002) How plant diversity and legumes affect nitrogen dynamics in experimental grassland communities. Oecologia, 133, 412-421.

Nesheim L. and B oller B.C. (1991) Nitrogen fixation by white clover when competing with grasses at moderately low temperatures. Plant and Soil, 133, 47-56.

Nie Z., Tremblay G.F., B Élanger G., Berthiaume R., Castonguay Y., Bertinand., Michaud R., Allard G. and HAN J. (2009) Near-infrared reflectance spectroscopy prediction of neutral detergent-soluble carbohydrates in timothy and alfalfa. Journal of Dairy Science, 92, 1702-1711.

Nyfeler D., Huguenin Elie O., Suter M., Frossard E., Connolly J. and L Üscher A. (2009) Strong mixture effects among four species in fertilized agricultural grassland led to persistent and consistent transgressive overyielding. Journal of Applied Ecology, 46, 683-691.

Nyfeler D., Huguenin-Elie O., Suter M., Frossard E. and L ÜSCHER A. (2011) Grass-legume mixtures can yield more nitrogen than legume pure stands due to mutual stimulation of nitrogen uptake from symbiotic and non-symbiotic sources. Agriculture Ecosystems and Environment, 140, 155-163. 
PAWITAN Y. (2001) In all likelihood: statistical modelling and inference using the likelihood. Oxford: Oxford University Press.

Paynel F., Lesuffleur F., Bigot J., Diquélou S. and Cliquet J.-B. (2008) A study of ${ }^{15} \mathrm{~N}$ transfer between legumes and grasses. Agronomy for Sustainable Development, 28, 281-290.

Pelletier S., Tremblay G.F., B élanger G., Bertrand A., Castonguay Y., Pageau D. and Drapeau R. (2010) Forage nonstructural carbohydrates and nutritive value as affected by time of cutting and species. Agronomy Journal, 102, 1388-1398.

Peyraud J.L., Le Gall A. and L üscher A. (2009) Potential food production from forage legume-basedsystems in Europe: an overview. Irish Journal of Agricultural and Food Research, 48, 115-135.

Reich P.B., Tilman D., Isbell F., Mueller K., Hobbie S.E., FlynN D.F.B. and Eisenhauer N. (2012) Impacts of biodiversity loss escalate through time as redundancy fades. Science, 336, 589-592.

S ANDERSON M.A. (2010) Nutritive value and herbage accumulation rates of pastures sown to grass, legume, and chicory mixtures. Agronomy Journal, 102, 728-733.

Schmid B., Hector A., Saha P. and Loreau M. (2008) Biodiversity effects and transgressive overyielding. Journal of Plant Ecology, 1, 95-102.

Sleugh B., Moore K.J., George J.R. and Brummer E.C. (2000) Binary legume-grass mixtures improve forage yield, quality, and seasonal distribution. Agronomy Journal, 92, 24-29.

Spehn E.M., Hector A., Joshi J., Scherer-Lorenzen M., Schmid B., Bazeley-White E., Beierkuhnlein C., Caldeira M.C., Diemer M., Dimitrakopoulos P.G., Finn J.A., Freitas H., Giller P.S., Good J., Harris R., Hogberg P., Huss-Danell K., Jumpponen A., Koricheva J., Leadley P.W., Loreau M., Minns A., Mulder C.P.H., O'Donovan G., Otway S.J., Palmborg C., Pereira J.S., Pfisterer A.B., Prinz A., Read D.J., Schulze E.D., Siamantziouras A.S.D., Terry A.C., Troumbis A.Y., Woodward F.I., Yachi S. and Lawton J.H. (2005) Ecosystem effects of biodiversity manipulations in European grasslands. Ecological Monographs, 75, 37-63.

Temperton V.M., Mwangi P.N., S cherer-Lorenzen M., Schmid B. and Buchmann N. (2007) Positive interactions between nitrogen-fixing legumes and four different neighbouring species in a biodiversity experiment. Oecologia, 151, 190-205.

TIL MAn D. (1997) Community invasibility, recruitment limitation, and grassland biodiversity. Ecology, 78, 81-92.

Tilman D., Reich P.B., Knops J., Wedin D., Mielke T. and LeHMAN C. (2001) Diversity and productivity in a long-term grassland experiment. Science, 294, 843-845.

Tracy B.F. and SAnderson M.A. (2004) Forage productivity, species evenness and weed invasion in pasture communities. Agriculture, Ecosystems and Environment, 102, 175-183.

Trenbath B.R. (1974) Biomass productivity of mixtures. Advances in Agronomy, 26, 177-210.

van Ruijven J. and Berendse F. (2003) Positive effects of plant species diversity on productivity in the absence of legumes. Ecology Letters, 6, 170-175.

Verbeke G. and Molenberghs G. (2000) Linear mixed models for longitudinal data. New York: Springer.

Wachendorf M., Collins R.P., Elgersma A., Fothergill M., Frankow - Lindierg B.E., Ghesquiere A., Guckert A., Guinchard M.P., Helgadottir A., L Üscher A., Nolan T., Nyk änenKurki P., N ösberger J., Parente G., Puzio S., Rhodes I., Robin C., Ryan A., Stäheli B., Stoffel S., Taube F. and Connolly J. (2001) Overwintering and growing season dynamics of Trifolium repens $\mathrm{L}$. in mixture with Lolium perenne L.: a model approach to plant-environment interactions. Annals of Botany, 88, 683-702.

Wilsey B.J. and Potvin C. (2000) Biodiversity and ecosystem functioning: importance of species evenness in an old field. Ecology, 81, 887-892.

Wilsey B.J., Chalcraft D.R., Bowles C.M. and Willig M.R. (2005) Relationships among indices suggest that richness is an incomplete surrogate for grassland biodiversity. Ecology, 86, 1178-1184.

WILSON J.B. (1988) Shoot competition and root competition. Journal of Applied Ecology, 25, 279-296.

WOLFINGER R. (1993) Covariance structure selection in general mixed models. Communications in Statistics Simulation and Computation, 22, 1079-1 106.

Zemenchik R.A., Albrecht K.A. and Shaver R.D. (2002) Improved nutritive value of kura clover- and birdsfoot trefoil-grass mixtures compared with grass monocultures. Agronomy Journal, 94, 1131-1138. 